\title{
Usage and China
}

This issue begins with the Fowlerian heritage: from The King's English in 1906 to A Dictionary of Modern American Usage in 1999.

In ET60 (Oct 99), I wrote a fairly well-disposed but nonetheless mildly exasperated review of the second of these titles, compiled by the Texas lawyer Bryan Garner, published by OUP New York, and chosen as a special selection of the Book of the Month Club in the States. In this issue, Garner replies both to me and to Richard Bailey of the University of Michigan, who wrote a rather more scathing review of $D M A U$ in a recent issue of the journal of the Dictionary Society of North America (No. 20,1999).

Garner's welcome article is followed by a historical piece by Rachel Ware, who is a master's student at the Dictionary Centre in the University of Exeter. Together, the two items tell an intriguing century-old tale about describing, prescribing, and proscribing. If anyone wishes to add to it, I will be happy to see the matter go further. The issues involved are larger than just usage books, fascinating as these works are; they relate to writing, editing, copyediting, proof-reading, the nature of the written and printed word, the question of whether we have or do not have a standard for world English, the question of whether languages in general need guardians, and whether this particular mammoth of a language needs a lot more guarding than most.

Which brings me to the other two complementary articles in this issue: the pieces on E-mail/e-mail/Email/email (and the realia I have added to them). These are the first significant features in ET on this subject, and both are by 'non-native' users of English: two mainland Chinese women scholars who have never met, who submitted their papers at about the same time, and who are both markedly alike and unalike in how they review the literature and their data. At the same time, both of them graphically demonstrate how the e-line blurs between English and other languages: in their specimens, we can see Putonghua mixing with English in remarkable ways. And this is only a tiny part of the vast and growing Chinese interface with English, likely to be one of the linguistic wonders of the new century. Watch this space.

Tom McArthur

The editorial policy of English Today is to provide a focus or forum for all sorts of news and opinion from around the world. The points of view of individual writers are as a consequence their own, and do not reflect the opinion of the editorial board. In addition, wherever feasible, ET generally leaves unchanged the orthography (normally British or American) and the usage of individual contributors, although the editorial style of the journal itself is that of Cambridge University Press. c) Cambridge University Press 2000 No contents may be reproduced by any means without the permission of Cambridge University Press.

English Today (ISSN 0266-0784) is a quarterly.

\section{Publisher:}

Cambridge University Press,

The Edinburgh Building, Cambridge CB2 2RU, United Kingdom. Telephone (01223) 312393 Email: journals_marketing@cup.cam.ac.uk Subscriptions: the current annual subscription price for four issues for libraries and institutions is $f 61$ outside North America; $\mathrm{f} 30$ for individuals; $\mathrm{f} 23$ for students and the retired. Prices include delivery by air where appropriate. Apply to Jane Crossland at the above address.

Advertising Sales: write to the

Advertising Promoter at the above address.

USA, CANADA AND MEXICO: Publisher:

Cambridge University Press, 40 West 20th Street, New York, NY 10011-4211, USA

Telephone (212) 9243900.

Subscriptions: the current annual subscription price in USA, Canada

and Mexico for libraries and

institutions is $\$ 98 ; \$ 50$ for

individuals; $\$ 36$ for students and

the retired. Apply to Joseph D.

Hranek at the above address. Advertising Sales: write to the

Advertising Coordinator at the above address.

Periodicals postage paid at New York, NY and at additional mailing offices.

POSTMASTER: send address changes in USA, Canada and Mexico to English Today, Cambridge University Press, 110 Midland Avenue, Port Chester, New York, NY 10573-4930, USA.

Japanese prices for institutions are available from Kinokuniya Company Ltd, P.O. Box 55, Chitose, Tokyo 156 Japan.

Letters to the Editor: write to Dr Tom McArthur, Editor, English Today, 22-23 Ventress Farm Court,

Cherry Hinton Road, Cambridge CB1 4HD, UK. Tel 01223245934 , Fax 01223241161.

Email: Scotsway@aol.com

This journal will shortly be included in the Cambridge Journals Online service which can be found at www.journals.cup.org. For further information on other Press titles access www.cup.cam.ac.uk or www.cup.org.

Printed in the United Kingdom by the University Press, Cambridge 